\title{
Quality of Public High School Education Analysis in Bekasi City After the Enactment of Zoning System
}

\author{
Zhafira Wirananda ${ }^{1}$, Amy Yayuk Sri Rahayu ${ }^{2}$ \\ zhafirawrnnd@gmail.com¹, amy_soeroso@yahoo.com² \\ ${ }^{1}$ Bachelor Student of Public Administration Department, Fakultas Ilmu Administrasi, Universitas \\ Indonesia, Depok 16424, Indonesia \\ ${ }^{2}$ Lecturer, Public Administration Department, Fakultas Ilmu Administrasi, Universitas Indonesia, Depok \\ 16426, Indonesia
}

\begin{abstract}
Zoning system policy for the 2017 New Student Admission which aimed for being able to equalize the quality of education in each school. The zoning system made school inputs become more heterogeneous. In educational process, changing inputs can influence the education process and output. This study aims to describe the quality of the education of Bekasi Public High Schools based on the educational process before and after the enactment of zoning system delivered by Tokuhama. This study used post-positivist method, in-depth interviews and literature studies as data collection techniques. The results of this study found that the quality of education in SMAN 1 Bekasi has not changed because they was able to maintain its quality, SMAN 5 Bekasi experienced a decline in quality due to the school's demand for students to follow and adjust in the learning process, also SMAN 15 Bekasi received benefits from the diversity of school inputs.
\end{abstract}

Keywords: education standards; learning process and results; the equality of education quality; zoning policies.

\section{Introduction}

Economic growth demand is become one of Indonesia's issues for reviewing policies and it is the most important perspective is human development [1]. The fundamental effort of human development is through improvement in the education sector. Based on the global issue, Ministry of Education and Culture Republic of Indonesia launched a 12-year compulsory education program to achieve equitable national education. The purpose of 12-year compulsory education program is to maintain continuity of the implementation of the previous program, the 9-year Compulsory Basic Education, which began in 1994 [2]. Hence, the government authorize the compulsory education program through The Constitution Number 47 of 2008 concerning Compulsory Education and Minister of Education and Culture Regulation Number 80 of 2013 concerning Universal Secondary Education. Thoseprogram concerned on rising the access and affordability of secondary education services which can be done by improving the quality, relevance, and equality of graduates to be produced.

Based on Ministry of Education and Culture's 2015-2019 Strategic Planning, the issue of education equity is only on its mission, but the strategic planning's goals is not intended to improve the problem of equity. The equal distribution of education itself includes the distribution of students in each school as well as quality distribution in each school in an area. One of the causes of the problem of educational equality is in the acquisition of educational services which formulated in strategic planning, the role of development education actor is not optimal yet. The strengthening teacher and education staff's role still still too much emphasis on improving the quality, competence and professionalism of teachers. This certainly has an impact on the quality of the implementation of 12-year compulsory education not yet maximized.

Therefore, Ministry of Education and Culture enact the policy of zoning system in The New Students Admission based on Ministry of Education and Culture Regulation Number 17 of 2017. That policy is also the implementation of the direction of President Joko Widodo about the 
importance of equitable education quality, drive the access improvement to 12-year educational services, and eliminate disparities in education participation between students with diverse economic backgrounds. The purpose of the change in the implementation of The New Students Admission according to Ministry of Education and Culture Regulation Number 17 of 2017 is to guarantee the acceptance of new students in an objective, transparent, accountable, nondiscriminatory and equitable in order to drive the access improvement to education services. According to Muhadjir as a Minister of Education and Culture, zoning system also used for strategic step on strategic steps in creating a quality educational equity so that it can overcome the problem of inequality in society [3].

Technically, zoning system requiring schools run by local governments to accept prospective students who live in the closest zone radius of the school at least $90 \%$ of the total number of accepted students no longer using the National Examination result. On 2017, which the first year the policy was implemented, the real implementation on the site did not go along with the policy's objective. The problems that arise include complaints about the zoning system, online registration with the problematic system, as well as requests for information of The New Students Admission. The Inspectorate General of the Ministry of Education and Culture received 240 complaints reports in the June-July 2017 period and the region that received the most irregularities during 2017 New Students Admission process was West Java Province, which has 38 complaints with the distribution of areas dominated by Bekasi, Bogor and Depok [4]. Among that three cities, the most junior high school (SMP) National Exam participants in 2018 were Bekasi City with a total of 31,691 participants [5]. Meanwhile, National Exam for junior high school (SMP) participants in Depok City totaling 27,285 and Bogor City 15,267. However, Bekasi City with the most junior high chool (SMP) National Exam participants, only has 22 public senior high school (SMA) so that it will not be able to accommodate all prospective learners entirely, even more so when using the zoning system.

Another problem is on the SMA Neutral Participation Rate which is one of the targets of the Key Performance Indicator (KPI) of the Bekasi City Education Department in 2017 in improving the quality and accessibility of education. Bekasi City has the lowest SMA Neutral Participation Rate among Depok dan Bogor City. Besides having the lowest Neutral Participation Rate, from year of 2017-2018, SMA Neutral Participation Rate in Bekasi City was decreasing which indicates that reduced participation of students participating in and continuing education to the high school level. The problem of its participation also supported by uneven distribution of high schools so that the impact as an obstacle in the initial implementation of the zoning system in the New Students Admission in Bekasi City. As a result, schools that located in near to the border between regions experience a dilemma related to quotas so that in some areas there is a lack of students, like SMAN 15 Bekasi which located in Bantar Gebang area, Villa Nusa Indah. On the other side, there is also schools that have a lot of applicants because they are located at dense zones such as in Pondok Gede sub-district but there is only one public high school namely SMAN 5 Bekasi.

Tabel 1.1 Passing Grade of Public High School in Bekasi City

\begin{tabular}{|c|c|c|c|c|}
\hline School & $\begin{array}{c}\text { Rayonization System } \\
\text { (Year of 2016) }\end{array}$ & $\begin{array}{c}\text { Year of } \\
\mathbf{2 0 1 7}\end{array}$ & Year of 2018 & Districts \\
\hline SMAN 1 Bekasi & 354.00 & 360.50 & 355.00 & Bekasi Timur \\
\hline SMAN 5 Bekasi & 331.50 & 337.00 & 337.00 & Pondok Gede \\
\hline SMAN 15 Bekasi & 276.50 & 263.00 & 268.00 & Bantar Gebang \\
\hline
\end{tabular}

sources: Processed by Researcher (2019)

Based on the result of SMA's New Students Admission in Bekasi City that obtained from the New Student Admission Online Archive, on year of 2017 which zoning system is not yet overall implemented and on year of 2018 after the zoning system has been implemented in each school, there was an increasing and decreasing of the passing grade from year to year. In 2016 to 2017 which still used the rayonization system, there was an enhancement in SMAN 1 and SMAN 5, this is because SMAN 5 is located in a strategic location and SMAN 1 Bekasi is the leading and favorite school in Bekasi City. However, when the zoning system was implemented in 2018, SMAN 1 Bekasi experienced a decrease on its passing grade and SMAN 5 Bekasi remained unchanged. Meanwhile, SMAN 15 Bekasi in 2016 to 2017 experienced a decrease due to its low school capacity which only 194 quota. Nevertheless, when the zoning system was put in place, SMAN 15 Bekasi actually experienced an increase in the results of the selection. Based on the 
selection results of The New Students Admission in SMAN 1, SMAN 5 and SMAN 15 Bekasi in the last three years, the implementation of the change of rayonization system to zoning system has a direct impact on each school such as student participation, educational equity, and easy access to education for students. Yet from the impacts that showed up directly, not yet seen the outcomes that affect the Human Development Index of West Java Province, especially Bekasi City itself. Consequently, based on the main problems that mentioned earlier, the researcher formulated the research question in this paper, namely How the Quality of Education in SMAN 1, 5, and 15 Bekasi After the Zoning System in New Students Admission (PPDB) was implemented?

\section{Research Method}

This study used post-positivist approach which makes it possible to identify and assess the results of observations based on observations and measurements of an objective reality of existing phenomena [6]. Based on post-positivist approach, the researcher used theory which is used as an absolute benchmark that can be used as a reference to assess the quality of education after the enactment of zoning system in the new student admission. The purpose of this research is to describe the quality of education in SMAN 1, 5, and 15 Bekasi after the enactment of zoning system in the new students admission so this paper chatagorized as a descriptive research. The data collection techniques that used in this study are qualitative because in gathering the required data, obtained through in-depth interviews as primary data sources and literature studies as secondary data sources. Informants for in-depth interviews are Manik Mustikohendro as Head of Educational Data Unit and Learning Process in Ministry of Education and Culture since the zoning system was developed there, Rina Imayanti as Head of Learning Section in Directorate of High School Development of the Ministry of Education and Culture since they appraise and evaluate public high school learning process, Toto as Complaint Service Officer for New Student Admission in West Java Provincial Education Department, vice principal on each school, and students representative on each school.

\section{Analysis}

Education is the fundamental thing for each human since it emphasized that the process and participation on education should be more relevant and follow through environment development from qualitative and universal viewpoint [7]. There are so many factors such as population growth, expanding the level of education and the development of the middle class, and continuity of communication and information technology development which are determinants of the increasing public demand for educational attainment. Therefore, technology and information development has been increasing competition in the education market, which leads to the efforts of public sector organizations to attract more and more students to participate in education [8]. The formation of education quality is often debated because of the different circumstances and conditions so that each country has its own standard or specifications to measure the success and quality of education. Tokuhama said that quality of education usually gets along with the interpretation of the user and often associated with the principle of effectiveness [7]. Besides, there is no specific standard that can be generally accepted on every country because of differences in values and culture in each region. Quality of education defined on different policy maker overview, governor, school manager, teacher, students, also parents. Even though there are different points of view, there is a common interest in educational outcomes which is relevant for all actors involved. In addition, by analyzing each of the characteristics of actors that involved in education, it can describe the impact of educational services and the generated value for the public interest [9].

Therefore, Tokuhama formulated quality of education indicators that was influenced by government policies namely standards, teachers and teaching, education retention and completion, and learning outcomes. The first indicator is standard is characteristic of the products and services that given or provided. In addition, the measurement of education standards is a measure of the quality of education that can determine by the efficiency of the educational services provided [10]. 
The purpose of standard measurement is to assess the education that given can run according to national curriculum and performance of education service servant. The measurement of education quality standards can be seen from the school standard achievement, the level of discipline of educational actors in schools, curriculum and use of technology, and the standards that apply to students which is in this case is the grade that used to pass to be accepted on school.

The second indicator is teachers and teaching which has main contribution in the learning process because it can affect the outcomes of student learning. As for improving the teaching and learning process, schools need to set a strategic planning such as vision and mission that is match to the curriculum, develop relevant content, use learning time properly, and ensure the effectiveness of teaching. The characteristics that can be used for measure teacher's learning method, experience, way of educating students, teacher training, also can be seen through the salary and benefits obtained by the teacher so that it can affect teacher's performance.

The third indicator is retention and compeletion that means stopping at a certain level or not completing in the middle of the learning process, stopping at the end of the school level because it cannot complete the level, or stopping between levels or unable to continue to the higher level. There are few of indicators that can measure quality of education based on retention such as percentage of graduation, the rate of level up, and dropout rates in an area. Last but not leat, the fourth indicator is academic achievement that used to measure student outcome learning process and it also can be used for measure student performance and evaluate the general education system such as curriculum and teachers. Standard on students' assessments are very important to communicate what has been achieved at a particular educational level and how it can be compared with the other achievements. Hence, academic achievement can be seen from the student outcomes that can be achieved which is emphasize on the students' final grades, not on the total number of graduations on each school.

\subsection{Education Standard}

Table 4.1 Education Standard

\begin{tabular}{|c|c|c|c|c|c|c|c|c|c|}
\hline \multirow{2}{*}{ Indicators } & \multicolumn{3}{|c|}{ SMAN 1 Bekasi } & \multicolumn{2}{c|}{ SMAN 5 Bekasi } & \multicolumn{2}{c|}{ SMAN 15 Bekasi } \\
\cline { 2 - 10 } & $\mathbf{2 0 1 6}$ & $\mathbf{2 0 1 7}$ & $\mathbf{2 0 1 8}$ & $\mathbf{2 0 1 6}$ & $\mathbf{2 0 1 7}$ & $\mathbf{2 0 1 8}$ & $\mathbf{2 0 1 6}$ & $\mathbf{2 0 1 7}$ & $\mathbf{2 0 1 8}$ \\
\hline $\begin{array}{c}\text { Student } \\
\text { Capacity }\end{array}$ & 398 & 245 & 360 & 340 & 216 & 360 & 360 & 194 & 360 \\
\hline Passing Grade & 354 & - & - & 331.5 & - & - & 276.5 & - & - \\
\hline Curriculum & K13 & K13 & K13 & K13 & K13 & K13 & K13 & K13 & K13 \\
\hline Infrastructure & 44 & 44 & 44 & 42 & 42 & 37 & 24 & 34 & 37 \\
\hline Strategy & \multicolumn{3}{|c|}{$\begin{array}{c}\text { There is specific } \\
\text { strategy after the } \\
\text { enactment of zoning } \\
\text { system. }\end{array}$} & $\begin{array}{c}\text { There is no specific } \\
\text { strategy after the } \\
\text { enactment of zoning } \\
\text { system. }\end{array}$ & \multicolumn{2}{c|}{$\begin{array}{c}\text { There is specific } \\
\text { strategy after the } \\
\text { enactment of zoning } \\
\text { system. }\end{array}$} \\
\hline
\end{tabular}

sources: Processed by Researcher (2019)

Based on table 4.1 above, before year of 2018, SMAN 1 Bekasi has the most quota and the least was SMAN 15 Bekasi. In 2017 there was a significant capacity decrease due to the implications of Law Number 23 of 2014 concerning Regional Government implementation which contains the division of authority between central and regional governments. One of contents on its regulation is education affairs for senior high school which now is held by the Provincial Government. In this case, Bekasi senior high school authority transfer is from Bekasi City Education Department to West Java Provincial Education Department. This affected to implementation of New Student Admission where the zoning system was just implemented in 2017. Based on interview result and literature study about zoning system in New Student Enactment, passing grade was no longer a benchmark or standard for New Student Admission in a school, so that in 2017 and 2018 passing grade was not a major concern for students and their schools. But in 2016, SMAN 1 Bekasi occupied the highest position for students' passing grade in Bekasi and SMAN 15 Bekasi has low passing grade.

Meanwhile the curriculum that used in SMAN 1, 5, and 15 Bekasi, both before and after the enactment of zoning system has already followed the standards that set by central government which is 2013 Curriculum. In terms of the availability of school infrastructure, there is no change 
in SMAN 1 Bekasi, while SMAN 5 Bekasi has changed by adding a laboratory with reducing six classrooms, and SMAN 15 Bekasi with rapid changes every year by adding five classrooms and a library in 2017 and added a class, a laboratory, and a library in 2018. Based on school strategy that implemented on each school, it can be concluded that with the input of students who have the lowest passing grade in 2016 throughout Bekasi City, the undertaken strategy by SMAN 15 Bekasi's teacher is to make students focus on learning the lesson takes place. Based on Citra's statement about the regulation it can be conluced that it was enough to made students stay focused during the class even though they have to reduce the quantity of study time. In summary, based on the statements that given by each school about their school standard that have mentioned before, even though school management does not give specific strategy for teacher after the enactment of zoning system, but the initiative of each teacher on every school, the strategy was good enough to impact the school to adapt to the conditions of existing students.

\subsection{Teachers and Teaching}

Table 4.2 Teachers and Teaching

\begin{tabular}{|c|c|c|c|}
\hline Indicators & SMAN 1 Bekasi & SMAN 5 Bekasi & SMAN 15 Bekasi \\
\hline Teachers & 67 & 54 & 47 \\
\hline $\begin{array}{l}\text { Certified } \\
\text { Teachers }\end{array}$ & 55 & 40 & 17 \\
\hline $\begin{array}{l}\text { Teachers } \\
\text { Training }\end{array}$ & $\begin{array}{l}\text { Trying to improve the } \\
\text { competency of his } \\
\text { teacher through in-house } \\
\text { training after the } \\
\text { enactment of zoning } \\
\text { system }\end{array}$ & $\begin{array}{l}\text { Did not make any } \\
\text { changes in the efforts } \\
\text { related to teacher } \\
\text { training in his school for } \\
\text { after the enactment of } \\
\text { zoning system }\end{array}$ & $\begin{array}{l}\text { Trying to improve the } \\
\text { competency of his } \\
\text { teacher through in-house } \\
\text { training after the } \\
\text { enactment of zoning } \\
\text { system }\end{array}$ \\
\hline $\begin{array}{l}\text { Teacher } \\
\text { Allowance }\end{array}$ & \multicolumn{3}{|c|}{$\begin{array}{l}\text { There is difference of teacher allowance between before and after the } \\
\text { enactment of zoning system }\end{array}$} \\
\hline $\begin{array}{l}\text { Learning } \\
\text { Method }\end{array}$ & $\begin{array}{l}\text { Teacher adjusts to } \\
\text { students condition in } \\
\text { each class after the } \\
\text { enactment of zoning } \\
\text { system }\end{array}$ & $\begin{array}{l}\text { Students adjust the } \\
\text { teacher's teaching } \\
\text { methods either before } \\
\text { and after zoning system }\end{array}$ & $\begin{array}{l}\text { Teacher adjusts to } \\
\text { students condition in } \\
\text { each class after the } \\
\text { enactment of zoning } \\
\text { system }\end{array}$ \\
\hline $\begin{array}{l}\text { Learning } \\
\text { Effectiveness }\end{array}$ & \multicolumn{3}{|c|}{$\begin{array}{c}\text { There was no change in the use of time or its quantity after the enactment of } \\
\text { zoning system }\end{array}$} \\
\hline
\end{tabular}

sources: Processed by Researcher (2019)

The table 4.2 is the interviews result and the interviewees are vice school principal and students at SMAN 1, 5, and 15 Bekasi. The statements that have been given indicate that after the enactment of zoning system, SMAN 1 and 15 Bekasi were trying to improve their teacher competency through in-house training in order to adjust to the curriculum and teaching design. Meanwhile, SMAN 5 Bekasi did not make any changes related to teacher training in their schools. Each school also mentioned that before and after the enactment of zoning system in New Students Admission, there was no difference in terms of teacher performance benefits. However, after the authority transfer from Bekasi City Education Department to West Java Provincial Education Department, teachers who teach in Bekasi City Public Senior High School were no longer get assistance from Bekasi City Government.

The issue of gap allowances is also mentioned in Surjaya's article that there is a difference between senior high school teacher's wages which managed by West Java Provincial Government and junior high and elementary school teachers which managed by Bekasi City Government [11]. It was also stated that the salaries of high school teachers were only paid 85 
thousand rupiah per hour meanwhile contract teachers in Bekasi City were given 3.8 million rupiahs per month. Based on analysis of teacher's qualifications, teachers in SMAN 1, 5, and 15 Bekasi participate in training every year although only SMAN 1 and 15 Bekasi who have special training programs for their teachers at school. However, teacher welfare problems are experienced by Bekasi City after the authority transfer to manage senior high school from city government to provincial government. Even with the difference in wages received before and after the zoning system, teachers keep continue to carry out their obligations to teach, maintain, and even increase output in their school.

Based on student statements in each school, today's learning process requires students to be more independent and initiative on learning, not only rely on teaching that given by their teachers at school. So the results can be obtained that SMAN 1 Bekasi is superior to other schools in term of the learning process. The school has qualified teachers and students who are enthusiastic about learning. Meanwhile, in SMAN 5 Bekasi which is in the middle rank based on the table above, it is inversely proportional to its implementation. The teachers at SMAN 5 Bekasi do not respond to the situation of the diversity of students in their schools so that were not much change that made in the learning process. This was also caused by the variety of teaching methods for teachers at the school. Unlike the case with SMAN 1 and 5 Bekasi, SMAN 15 Bekasi is in the lowest rank based on the table above. Basically, their teachers and students have a high enthusiasm for the teaching process. It can be seen by teacher efforts to adjust their teaching methods that are suitable for their students.

\subsection{Retention and Completion}

In this study, retention and completion can be seen from comparison of student inputs and outputs who take lessons in each school. The measurement is also accordance with the indicators of Indonesia education development. Therefore, in analyzing the dimensions of education retention and completion, it can be measured by the total students that have not pass to the next level each year. In this case, there are no graduates for students in 2017/2018 school year because it was the first year that zoning system in New Students Admission implemented. Therefore, in conducting retention analysis in this study is to compare the grade promotion's rates and dropout rates at SMAN 1, 5, and 15 Bekasi.

Table 4.3 Retention and Completion

\begin{tabular}{|c|c|c|c|c|c|c|c|c|}
\hline \multicolumn{3}{|c|}{ SMAN 1 Bekasi } & \multicolumn{3}{c|}{ SMAN 5 Bekasi } & \multicolumn{3}{c|}{ SMAN 15 Bekasi } \\
\hline 2016 & $\mathbf{2 0 1 7}$ & $\mathbf{2 0 1 8}$ & $\mathbf{2 0 1 6}$ & $\mathbf{2 0 1 7}$ & $\mathbf{2 0 1 8}$ & $\mathbf{2 0 1 6}$ & $\mathbf{2 0 1 7}$ & $\mathbf{2 0 1 8}$ \\
\hline- & - & - & 1 & 2 & 4 & 1 & - & - \\
\hline
\end{tabular}

Sources: Processed by Researcher (2019)

Based on data obtained from this research for retention and completion dimensions which collected from in-deepth interview with each school vice principal, only SMAN 1 Bekasi who has no dropouts or does not graduate meanwhile SMAN 5 Bekasi has students who dropout of school and there are students who did not graduated each year. Besides, SMAN 15 Bekasi students who did not pass the level only happened on two years ago which is on the 2016/2017 school year, when the zoning system in New Students Admission was not yet in force. In general, Bekasi City still has senior high school students who have not graduated or dropped out of school.

\subsection{Academic Achievement}

Academic achievement can also be measured by students learning development and individual skills and knowledge. Student assessment standard is important to communicate things that achieved from each education level. Therefore in evaluating learning process, it is necessary to be consistent in determining the standards. Based on the analysis that has been done above related to the assessment standards in Bekasi City senior high school, each school has made adjustments to the standards. The adjustment was made due to changes in raw input at each school. Due to the diversity of existing students, SMAN 1 and 5 Bekasi reduce the value of their assessment standards. Meanwhile SMAN 15 Bekasi received a positive impact from the zoning system itself, stated that they need to improve their assessment standard in order to remain competitive with other schools. The other standards used by the three values are personality or attitude values. This value is also used by schools as an assessment standard that can affect student output and learning outcomes.

Table 4.4 Academic Achievement 


\begin{tabular}{|c|c|c|c|c|c|c|c|c|c|c|}
\hline \multirow{2}{*}{\multicolumn{2}{|c|}{ Indicators }} & \multicolumn{3}{|c|}{ SMAN 1 Bekasi } & \multicolumn{3}{|c|}{ SMAN 5 Bekasi } & \multicolumn{3}{|c|}{ SMAN 15 Bekasi } \\
\hline & & 2016 & 2017 & 2018 & 2016 & 2017 & 2018 & 2016 & 2017 & 2018 \\
\hline \multicolumn{2}{|c|}{ Assessment Standard } & 76 & 70 & 70 & 77 & 75 & 75 & 62 & 70 & 70 \\
\hline \multirow{3}{*}{$\begin{array}{c}\text { Average } \\
\text { Results }\end{array}$} & $\begin{array}{l}\text { Science } \\
\text { Student }\end{array}$ & 88 & 85 & 83 & 85 & 83 & 81 & 80 & 82 & 80 \\
\hline & $\begin{array}{l}\text { Social } \\
\text { Student }\end{array}$ & 86 & 82 & 82 & 85 & 82 & 80 & 79 & 80 & 81 \\
\hline & $\begin{array}{c}\text { Linguistic } \\
\text { Student }\end{array}$ & - & - & - & - & - & - & - & - & 80 \\
\hline
\end{tabular}

Sources: Processed by Researcher (2019)

Table 4.4 above shows students' academic achievement before and after the enactment of zoning system that gotten from each school. It can be concluded that at SMAN 1 Bekasi learning outcomes was decreased each year, both in science and social students. This is in accordance with the statement mentioned by the students of SMAN 1 Bekasi on their interview. This also happened at SMAN 5 Bekasi and also supported by Rahmat's statements as SMAN 5 Bekasi vice principal and their students who was the interviewees in this study. However, SMAN 15 Bekasi has different condition. In year of 2016 and 2017, their students' grades have increased due to the assessment standards rising that have been explained by Dhayu as the vice school principal and Citra as a student who experienced the change. Yet in 2018, the grade of science students at SMAN 15 Bekasi has decreased again but the social students' grade is increased and there was linguistic class on their school. Thus it can be concluded that the average test results in SMAN 1 and 5 Bekasi have decreased, while SMAN 15 Bekasi has increased due to they have rised their assessment standard and also the zoning system has a positive impact on their schools.

\section{Conclussion}

The zoning system policy in New Student Admission aims to equalize the quality of education and also change education standards and criteria for student to get educational services. The diversity input which caused by the enactment of zoning system affect students learning process and its result. Based on the education quality analysis that has been done on previous chapter, it can be concluded that SMAN 1 Bekasi has no quality improvement after the enactment of zoning system. This is happened because before the enactment of zoning system, SMAN 1 Bekasi had already reached the standard of education products and services, their teachers had already dominated by qualified teachers, they have none students who did not pass the level, yet the average of students' learning outcomes from 2016-2018 were decreasing. SMAN 5 Bekasi who used to have good quality students on their input before the enactment of zoning system, was unable to adjust the educational services that have to be delivered by them so that its quality was decreased. It can be seen by even though SMAN 5 Bekasi has reached the standard of education products and services, there are still many unqualified teachers and the teachers were unable to adjust the diversity of their existing students, also the quantity of students who do not pass the level was rising every year, and there has been a decreased in learning outcomes in the last three years. Meanwhile SMAN 15 Bekasi experienced an increase on their education quality after the enactment of zoning system. It is proved by their school had already reached and followed the standard educational products and services, the teachers on learning prosess adjusting the conditions of their existing students even their school are dominated by teachers who are not yet qualified, all of SMAN 15 Bekasi students also pass the level after the enactment of zoning system 
unlike before the enactment of zoning system, and there is an increase in learning outcomes each year at SMAN 15 Bekasi. According to the study that has been done, it can be concluded that the zoning system provides benefits for schools that were previously have poor quality students input. But for schools that have a stigma of favorite schools, it is depends on their efforts of each schools to adjust the learning process and services provided with diverse input from the existence of this zoning system on New Students Admission.

\section{Recommendation}

Based on existing problems, SMAN 1, 5, and 15 Bekasi need to standardize their strategies and teaching methods that are applied primarily to adjust to the diversity of students on each school so that the equality of educational quality as a purpose the enactment of zoning system is achieved. Besides, Ministry of Education and Culture as policy maker has to do an intensive collaboration with the Ministry of Research, Technology, and Higher Education to promote teacher certification and pressure teachers to have equal qualifications between schools. Also West Java Provincial Education Department needs to equalize the quantity and quality of certified teachers in each school in Bekasi City Senior High School and need to evaluate the accuracy of the zoning system implementation and formulate a strategic planning specifically to equalize education and service standards at each school in their region. Last but not least, West Java Provincial Education Department with Directorate of High School Development needs to sharpen education appraisal so that the objectives of the zoning system in each school can be achieved.

\section{Acknowledgement}

This research funded by PITMA-B which granted by Universitas Indonesia.

\section{References}

\section{Bibliography}

[1] ASEAN Secretariat News, "Higher Education in ASEAN to Enhance Student Mobility in the Region," 2017. [Online]. Available: asean.org: https://asean.org/highereducation-in-asean-to-enhance-student-mobility-in-theregion/?highlight=education.

[2] R. Imayanti, Interviewee, In Depth Interview with Head of Section for Learning Division of the Directorate of High School Development Ministry of Education and Culture. [Interview]. 31 May 2019.

[3] Ministry of Education and Culture, "Rencana Strategis Kementerian Pendidikan dan Kebudayaan 2015-2019," Ministry of Education and Culture, Jakarta, 2015.

[4] Media Indonesia, "Kemendikbud: Pengaduan Masalah PPDB Paling Banyak di Jawa Barat," 2017. [Online]. Available: http://mediaindonesia.com/read/detail/112473kemendikbud-pengaduan-masalah-ppdb-paling-banyak-di-jawa-barat.

[5] R. Apinino, "Empat Kelemahan Sistem Zonasi dalam PPDB 2018," 2018. [Online]. Available: https://tirto.id/empat-kelemahan-sistem-zonasi-dalam-ppdb-2018-cNP9.

[6] J. Creswell, Research Design: Qualitative, Quantitative and Mixed Method 
Approach, Fourth Edition ed., California: SAGE Publications, 2013.

[7] T. Tokuhama, M. Rivera, C. Tobar, I. Solano, S. Proaño, M. Tirira and I. Merino, "International Indicators of Quality Education: How Economic Status, Units of Analysis and Culture Can Influence Country Choices of Key Quality Indicators in Education," in the World Education Research Association (WERA) Focal Meeting and 12th National Conference on Educational Research, Guanajuato, Mexico, 2013.

[8] G. Dimitriadis and G. Kamberelis, "Theory for Education," London, 2006.

[9] J. Kee and K. Newcomer, Transforming Public and Nonprofit Organizations, Vienna: Management Concepts, 2008.

[10] H. Tilaar, Standarisasi Pendidikan Nasional: Suatu Tinjauan Kritis, Jakarta: Rineka Cipta, 2006.

[11] A. M. Surjaya, "Ingin Kesejahteraan Guru Meningkat, Pemkot Bekasi Ngotot Kelola SMA," 2018. [Online]. Available: metro.sindonews.com:

https://metro.sindonews.com/read/1345474/171/ingin-kesejahteraan-gurumeningkat-pemkot-bekasi-ngotot-kelola-sma-1539261697. . 